Müjgan Dogan Onugoren, MD*

Kristin S. Golombeck, MD*

Corinna Bien, MD

Mariam Abu-Tair, MD

Marcus Brand, MD

Michael Bulla-Hellwig, $\mathrm{PhD}$

Hubertus Lohmann, PhD

Dieter Münstermann, $\mathrm{PhD}$

Hermann Pavenstädt, MD

Gerold Thölking, MD

Rainer Valentin, MD

Heinz Wiendl, MD

Nico Melzer, MD*

Christian G. Bien, MD*

Correspondence to

Dr. Dogan Onugoren:

muejgan.dogan@uk-erlangen.de

\section{Immunoadsorption therapy in autoimmune encephalitides}

\section{OPEN}

\section{ABSTRACT}

Objective: It was hypothesized that in encephalitides with autoantibodies directed to CNS surface antigens an antibody-removing intervention might speed up recovery.

Methods: The outcome of autoimmune encephalitis in 19 patients with antibodies against surface antigens (leucine-rich, glioma inactivated 1 [LGI1], $n=3$; contactin-associated protein-2 [CASPR2], $n=4$; NMDA receptor [NMDAR], $n=7$ ) and intracellular antigens (glutamic acid decarboxylase [GAD], $\mathrm{n}=5$ ) after immunoadsorption in addition to corticosteroid therapy was evaluated retrospectively. Modified Rankin scale (mRS) scores and data on seizures, memory, and antibody titers directly after immunoadsorption (early follow-up) and after a median of 4 months (late follow-up) were compiled.

Results: Immediately after immunoadsorption, 9 of 14 patients with antibodies against LGI1, CASPR2, or NMDAR (64\%), but none with GAD antibodies, had improved by at least one mRS point. Five of the 7 patients with LGI1 or CASRP2 antibodies had become seizure-free, and 2 patients with NMDAR antibodies had a memory improvement of more than 1 SD of a normal control population. At late follow-up, 12 of 14 patients with surface antibodies had improved (86\%), and none of the patients with GAD antibodies.

Conclusions: It is suggested that addition of immunoadsorption to immunosuppression therapy in patients with surface antibodies may accelerate recovery. This supports the pathogenic role of surface antibodies.

Classification of evidence: This study provides Class IV evidence that immunoadsorption combined with immunosuppression therapy is effective in patients with autoimmune encephalitis with surface antibodies. Neurol Neuroimmunol Neuroinflamm 2016;3:e207; doi: 10.1212/NXI.0000000000000207

\section{GLOSSARY}

CASPR2 = contactin-associated protein-2; DCS-R = Diagnostikum für Cerebralschädigung, revised version; GAD = glutamic acid decarboxylase; IA = immunoadsorption; IA-IS = antibody-removing therapy with immunosuppression; IgG = immunoglobulin G; IVIg = IV immunoglobulin; LGI1 = leucine-rich, glioma inactivated 1; mRS = modified Rankin Scale; NMDAR = NMDA receptor

Autoimmune encephalitides can be associated with surface or nonsurface antibodies. ${ }^{1,2}$ Antibodies against NMDA receptor (NMDAR), ${ }^{3}$ leucine-rich, glioma inactivated 1 (LGI1), or contactin-associated protein-2 (CASPR2) are frequent. ${ }^{4-7}$ Intracellular antigenic targets are onconeural proteins like $\mathrm{Hu}$ and $\mathrm{Ma} 1 / 2^{8}$ or glutamic acid decarboxylase (GAD) in its $65-\mathrm{kD}$ isoform. ${ }^{9}{ }^{10}$ Neuropathologic data suggest a relevant contribution of T cells in nonsurface antibodies. ${ }^{11,12}$ A direct pathogenic effect of NMDAR and LGI1 antibodies has been suggested by in vitro experiments ${ }^{13,14}$ and neuropathologic studies on human brain tissue. ${ }^{12}$ Recently, the Barcelona group reported the first passive-transfer animal experiments with NMDAR

\footnotetext{
*These authors contributed equally to this work.

From the Epilepsy Center Bethel (M.D.O., C.B., M.B.-H., C.G.B.), Krankenhaus Mara, Bielefeld; Department of Neurology (M.D.O.), University Hospital Erlangen; Department of Neurology (K.S.G., H.L., H.W., N.M.), University of Münster; Department of Nephrology (M.A.-T., R.V.), Bethel-EvKB, Bielefeld; Department of Medicine D (M.B., H.P., G.T.), Division of General Internal Medicine, Nephrology and Rheumatology, University Hospital of Münster; and Laboratory Krone (D.M.), Bad Salzuflen, Germany.

Funding information and disclosures are provided at the end of the article. Go to Neurology.org/nn for full disclosure forms. The Article Processing Charge was paid by Gesellschaft für Epilepsieforschung, Bielefeld e.V.

This is an open access article distributed under the terms of the Creative Commons Attribution-NonCommercial-NoDerivatives License 4.0 (CC BY-NC-ND), which permits downloading and sharing the work provided it is properly cited. The work cannot be changed in any way or used commercially.
} 
antibodies. ${ }^{15}$ Classical studies in myasthenia gravis demonstrated remission by removal of acetylcholine receptor antibodies, ${ }^{16,17}$ lending strong support to the direct pathogenic effect of these antibodies. ${ }^{18}$ This and the diseasetransferring effect of antibody injection into animals ${ }^{19}$ make myasthenia gravis a paradigm of neurologic antibody-mediated conditions. Immunoadsorption (IA), a refined form of plasma exchange, ${ }^{20}$ is an option within the therapeutic armamentarium for autoimmune conditions of the CNS. ${ }^{21,22}$ The idea is that a reduction of serum antibodies also reduces antibodies in CSF and finally in the CNS itself.

At present, there are no evidence-based treatment standards for antibody-associated encephalitides. Many neurologists use corticosteroids, but apheresis or IV immunoglobulin (IVIg) have also been suggested as first-line treatments. $^{3}$

METHODS The purpose of our study was to investigate whether addition of antibody-removing therapy to immunosuppression (IA-IS therapy) accelerates recovery of patients with proven autoimmune encephalitis and surface antibodies or antibodies to intracellular antigens. ${ }^{23}$

From June 2011 to May 2015, 30 patients were treated with IA because of definite or suspected autoimmune encephalitis. Eleven patients were excluded due to incomplete data or doubts about the validity of the diagnosis. The remaining 19 patients were either immunotherapy-naive $(n=5)$ or had received immunotherapeutic interventions before without effect $(n=14)$. Fifteen patients were treated in the Epilepsy Centre Bielefeld-Bethel, Germany, a tertiary referral center, and 4 in the Department of Neurology, University of Münster, Germany. Clinical information was compiled retrospectively by medical record review. Data were recorded for 3 time points: baseline (before IA treatment), early follow-up (directly after IA), and late follow-up several months after IA. Patients had limbic encephalitis (with LGI1 or CASPR2 antibodies, $\mathrm{n}=7),{ }^{5-7}$ anti-NMDAR encephalitis $(\mathrm{n}=7),{ }^{24}$ or immune-mediated temporal lobe epilepsy with GAD antibodies $(\mathrm{n}=5) \cdot{ }^{25,26}$ One patient had a neoplasm (NMDAR-F, small cell lung cancer). For demographic details and immunologic treatments given prior to IA, see table 1 .

Modified Rankin Scale (mRS) scores were determined retrospectively and independently by 2 investigators per patient; one knew the patient, the other one rated from the records. In cases of divergent ratings (maximum difference was $1 \mathrm{mRS}$ point), the mean was noted. A change of \pm 1 point was considered deterioration/improvement. ${ }^{27}$ Values $\leq 2$ indicate independent living of the patient, values $>2$ increasing degrees of dependency. ${ }^{27}$ Seizure frequencies are expressed as per week and relate to following time periods: baseline, preceding 4 months or (if this was shorter) time from symptom onset; at early follow-up, the previous week; at late follow-up, time since last IA session. For memory assessment, the Verbal Learning and Memory Test, the German adaptation of the Rey Auditory Verbal Learning Test, ${ }^{28}$ and the Diagnostikum für Cerebralschädigung, revised version
(DCS-R) for figural memory ${ }^{29}$ were used. In Münster patients, the Rey-Osterrieth Complex Figure Test ${ }^{30}$ was applied instead of DCS-R. The $z$ scores of verbal and figural tests ${ }^{10}$ were averaged. Eight values out of the potential 57 (19 patients $\times 3$ time points [14\%]) are missing. Five patients received 2 IA sequences because of an assumedly incomplete effect of the first one. Their analyses were performed on first IA sequence and its outcome. Follow-up after second IA round is only descriptively reported. This study provides Class IV evidence because of a lacking control group and masked outcome assessment.

Standard protocol approvals, registrations, and patient consents. All patients underwent IA based on an individual informed written consent of the patient or his or her representatives (compassionate use).

Antibody determination. Antibody specificities and titers for all patients were determined in the Bethel antibody laboratory using cell-based assays in the form of commercially available biochips (Euroimmun, Lübeck, Germany). Complementary DNAs for known antigens are inserted into eukaryotic expression vectors. Plasmids are subsequently transfected into HEK293 cells. These cells are seeded on cover glasses by use of polyethylenimine. Forty-eight hours after transfection, cells are fixed with paraformaldehyde (LGI1, CASPR2, and other antigens, not relevant for this study) or acetone (NMDAR with NR1 subunits only and GAD65). Coated cover glasses are cut into $1 \times 1 \mathrm{~mm}$ fragments and assembled to mosaics in defined orders. For titration purposes, slides containing 5 double fields (1 with HEK cells transfected with the antigen of interest and 1 with nontransfected control cells) are used. Biochips are stored at $4^{\circ} \mathrm{C}$ and used on demand. We followed the manufacturer's instructions with modifications. For detection of antibodies, serum at 1:15 and undiluted CSF are incubated with biochips for 30 minutes at room temperature. The secondary system consists of a goat-anti-human immunoglobulin G (IgG) (heavy and light chain) antibody conjugated with Alexa Fluor 594 produced by Jackson ImmunoResearch (West Grove, PA, code 109-585-088) at a dilution of 1:100. Nuclei are counterstained with Hoechst 33342, diluted 1:10,000. Both incubate at room temperature (anti-IgG: 30 minutes, Hoechst 33342: 10 minutes). Finally, cover glasses are put on antifading mounting medium 11,4-diazabicyclo (2.2.2) octane (1\%). Stained biochips are examined using a fluorescence microscope (Leica DM 2000; Wetzlar, Germany) with excitation at $592 \mathrm{~nm}$ and emission filter at $616 \mathrm{~nm}$ for bound antibody and 350/462 $\mathrm{nm}$ for nuclear counterstain. The decision if an antibody is present in the tested material is done by 1 of 3 investigators (C.G.B., C.B., M.D.O.). Titers of antibodies are determined at 1:2 steps. Two persons rate titration stainings independently. In cases of divergent ratings, the mean is recorded. In 16 out of a potential 114 samples, no material for titration was available (14\%). In Bielefeld-Bethel, sera were stored and titrated, having been obtained directly prior to an IA session and directly afterwards.

Therapeutic intervention. This was not a prospective study. Orienting suggestions for applications, dosages, treatment durations, and follow-up schedules were agreed upon among the physicians in the participating neurologic and nephrologic departments (figure 1A). The scheme was modified individually according to patients' properties, preferences, or organizational circumstances. For immunoadsorption, vascular access was obtained by an indwelling Shaldon catheter inserted into the internal jugular vein. Plasma is separated from corpuscular blood components. Plasma filtrate passes through either a regenerative double column system (Immunosorba Fresenius 


\begin{tabular}{|c|c|c|c|c|c|c|c|c|c|c|c|c|}
\hline \multicolumn{13}{|c|}{ Table 1 Individual patients' characteristics at baseline } \\
\hline $\begin{array}{l}\text { Antibody and patient } \\
\text { no., sex, age at onset, } \\
\text { y, institution }\end{array}$ & $\begin{array}{l}\text { Disease } \\
\text { duration, } \\
\text { mo }\end{array}$ & Previous immunotherapy & $\begin{array}{l}\text { Interval } \\
\text { to IA-IS }\end{array}$ & Diagnosis & $\begin{array}{l}\text { Encephalitis- } \\
\text { related MRI } \\
\text { lesions }\end{array}$ & $\mathrm{mRS}$ & Seizures/wk & $\begin{array}{l}\text { Memory, z } \\
\text { scores }\end{array}$ & $\begin{array}{l}\text { Serum } \\
\text { antibodies, } \\
\text { titers 1:n }\end{array}$ & $\begin{array}{l}\text { CSF } \\
\text { antibodies, } \\
\text { titers 1:n }\end{array}$ & $\begin{array}{l}\text { IA system } \\
\text { and no. } \\
\text { sessions }\end{array}$ & Tumor \\
\hline LGI1-A, M, 51, BI & 9.5 & $10 \mathrm{~d}$ : MP pulse $5 \mathrm{~g}$, then Pred $80 \mathrm{mg} / \mathrm{d}$ & None & LE & $\begin{array}{l}\text { Hypersignal R } \\
\text { temp-med }\end{array}$ & 3 & 42 & -0.4 & 32 & 0 & Fres, 10 & None \\
\hline LGI1-B, F, 66, BI & 13.0 & 2 wk: Pred $80 \mathrm{mg}$ & None & LE & $\begin{array}{l}\text { Hypersignal L } \\
\text { temp-med }\end{array}$ & 4 & 37.5 & -1.7 & 200 & 0 & $\mathrm{Dia}, 10$ & None \\
\hline LGI1-C, M, 63, BI & 41.0 & $\begin{array}{l}3 \mathrm{y} \text { : IVlg } 150 \mathrm{~g}, \text { PEX } 4 \times \text {, Pred } 100 \mathrm{mg} / \mathrm{d} \text {, tapered } \\
\text { over several wk, MP pulse } 5 \mathrm{~g}\end{array}$ & None & LE & HS L & 2.5 & 50.5 & -0.3 & 2,000 & 8 & Dia, 8 & None \\
\hline CASPR2-A, 74, BI & 6.0 & $\begin{array}{l}6 \mathrm{mo:} 3 \mathrm{MP} \text { pulses, } 1 \text { cyclophosphamide infusion, } \\
\text { Pred } 20 \mathrm{mg} / \mathrm{d}\end{array}$ & None & LE & $\begin{array}{l}\text { Hypersignal } \\
\text { amygdalae bilateral }\end{array}$ & 3.5 & 7 & -1.8 & 500,000 & 128 & Fres, 10 & None \\
\hline $\begin{array}{l}\text { CASPR2-B, M, 55, } \\
\text { Münster }\end{array}$ & 0.9 & None & NA & LE & $\begin{array}{l}\text { Hypersignal L > R } \\
\text { temp-med }\end{array}$ & 3 & 225 & -0.7 & 500 & 0 & Fres, 5 & None \\
\hline $\begin{array}{l}\text { CASPR2-C, 65, } \\
\text { Münster }\end{array}$ & 3.7 & None & NA & LE & $\begin{array}{l}\text { Hypersignal L > R } \\
\text { temp-med }\end{array}$ & 3 & 7 & -1.4 & ND & 2,000 & Fres, 5 & None \\
\hline CASPR2-D, M, 70, BI & 16.0 & $5 \mathrm{~d}:$ MP pulse $2.5 \mathrm{~g}$ & None & LE & $\begin{array}{l}\text { Hypersignal R } \\
\text { temp-med }\end{array}$ & 3 & 25 & -1.4 & 2,000 & 500 & $\mathrm{Dia}, 10$ & None \\
\hline NMDAR-A, M, 15, BI & 7.7 & $6 \mathrm{~d}:$ MP pulse $6 \mathrm{~g}$, IVlg $120 \mathrm{~g}$ & None & $\begin{array}{l}\text { Anti-NMDAR-E, } \\
\text { 2nd bout }\end{array}$ & None & 5 & 0.25 & -3.0 & 3,000 & 128 & Fres, 10 & None \\
\hline NMDAR-B, F, 19, BI & 1.2 & $1 \mathrm{mo}:$ MP pulse $4 \mathrm{~g}$ & 4 wk & Anti-NMDAR-E & None & 4.5 & 0.25 & -1.3 & 0 & 3 & $\mathrm{Dia}, 10$ & None \\
\hline NMDAR-C, F, 24, BI & 0.3 & $6 \mathrm{~d}$ : MP pulse $5 \mathrm{~g}$ & None & Anti-NMDAR-E & None & 5 & 0.25 & -3.0 & 2,000 & 128 & Dia, 10 & None \\
\hline $\begin{array}{l}\text { NMDAR-D, F, 23, } \\
\text { Münster }\end{array}$ & 0.5 & $5 \mathrm{~d}:$ MP pulse $2.5 \mathrm{~g}$ & None & Anti-NMDAR-E & Frontal L & 5 & 0 & -2.0 & ND & 250 & Fres, 8 & None \\
\hline NMDAR-E, F, 30, BI & 36.0 & $2 \mathrm{y}$ : PEX $4 \times$; Pred tapered to $1 \mathrm{mg} / \mathrm{d}$ & None & Anti-NMDAR-E & HS L & 4.5 & 0 & -1.7 & 64 & 64 & Dia, 9 & None \\
\hline $\begin{array}{l}\text { NMDAR-F, F, 51, } \\
\text { Münster }\end{array}$ & 0.9 & None & None & Anti-NMDAR-E & None & 5 & 0 & -3.0 & 2,000 & 1000 & Fres, 5 & SCLC \\
\hline NMDAR-G, F, 18, BI & 6.1 & $25 \mathrm{~d}:$ MP pulse, then Pred $80 \mathrm{mg} / \mathrm{d}(6,600 \mathrm{mg})$ & None & Anti-NMDAR-E & None & 3 & 0 & -0.1 & 8,000 & 32 & Fres, 10 & None \\
\hline GAD-A, F, 36, BI & 41.0 & $1.8 \mathrm{y}:$ Pred $80 \mathrm{mg} / \mathrm{d}$, tapered & $1.5 \mathrm{y}$ & GAD-TLE & None & 2.5 & 2.15 & 0.1 & 250,000 & 12 & Dia, 10 & None \\
\hline GAD-B, M, 30, BI & 4.0 & None & NA & GAD-TLE & None & 2 & 1.25 & 0.2 & 32,000 & 16 & Dia, 10 & None \\
\hline GAD-C, F, 28, BI & 132.0 & $\begin{array}{l}1.5 \mathrm{y} \text { : MP pulse } 2.3 \mathrm{~g} ; \text { Pred } 80 \mathrm{mg} / \mathrm{d} \text { tapered to } \\
7.5 \mathrm{mg} / \mathrm{d} ; 11 \mathrm{mo} \text { + AZA } 100 \mathrm{mg} / \mathrm{d}\end{array}$ & None & GAD-TLE & None & 2 & 1.25 & ND & 8,000 & 250 & $\mathrm{Dia}, 10$ & None \\
\hline GAD-D, F, 59, BI & 336.0 & None & NA & GAD-TLE & None & 4 & 2.75 & -1.7 & 32,000 & 16 & Dia, 10 & None \\
\hline GAD-E, F, 37, BI & 70.0 & $2.5 \mathrm{y}$ : MP pulse $5 \mathrm{~g}$ & $2.5 \mathrm{y}$ & GAD-TLE & None & 2 & 3.75 & -0.3 & 1,500 & 2 & Dia, 10 & None \\
\hline
\end{tabular}

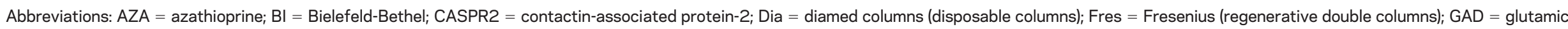

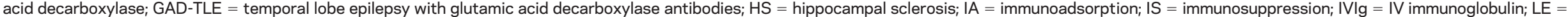

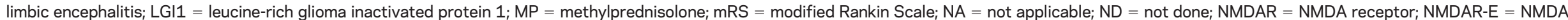
receptor encephalitis; PEX = plasma exchange; Pred = prednisolone; temp-med = temporomedial; SCLC = small cell lung carcinoma.

${ }^{a}$ Evolved into HS. 
Medical Care, Bad Homburg, Germany) with $1.5-2$ plasma volumes (Münster, $\mathrm{n}=4$ ) or 2 to 2.2 plasma volumes (Bielefeld-Bethel, $\mathrm{n}=4$ ) processed or a disposable tryptophan column (Immunosorba TR-350, Octonova Technology, Diamed Medizintechnik GmbH, Cologne, Germany; 2 L plasma per session, $\mathrm{n}=11$, all done in Bielefeld-Bethel). At onset, 2 to 3 sessions were done on consecutive days. Thereafter, intervals were 2 to 3 days. One IA sequence consisted of 10 sessions in BielefeldBethel (except for patient NMDAR-E with 9 sessions and LGI1C with 8 sessions) and 5 in Münster (NMDAR-D received 8 sessions). Average material costs per IA session were about $\$ 2,200-\$ 2,800$ USD. All patients except one (NMDAR-D) received prednisolone in parallel (median dose $4.9 \mathrm{~g}$, range 1.4-16 g). Before IA, 5 patients had been treated with other immunotherapies (plasma exchange: $\mathrm{n}=2$, NMDAR-E and LGI1-C; IVIg: $\mathrm{n}=2$, NMDAR-A and LGI1-C; azathioprine: $\mathrm{n}=1$, GAD-C; and cyclophosphamide: $\mathrm{n}=1$, CASPR2-A; for further details, see table 1).

RESULTS Patients had antibodies against LGI1 $(\mathrm{n}=3$; disease duration 13 [range 9.5-41] months), CASPR2 ( $\mathrm{n}=4$; 4.8 [range 0.9-16] months), NMDAR ( $\mathrm{n}=7$, all had CSF antibodies; disease duration 1.2 [range 0.3-36] months), or GAD ( $\mathrm{n}=5$, all with high serum titers $\geq 1: 1,500$ and CSF antibodies; 8 years [range 4 months- 28 years]). Individual data on all patients at baseline and follow-up time points are given in tables 1 and 2. At early follow-up (median 5 days after the last IA, range 0-43 days), serum and CSF titers decreased by a median of $97 \%$ and $64 \%$, respectively, in the whole group. At late follow-up (median lag: 3.9 months, range 2.4-8.7 months), median decrease rates were 97\% (serum) and $88 \%$ (CSF). Individual patient titer changes are given in figure $1, \mathrm{~B}$ and $\mathrm{C}$. Course of serum titers during the sequence of IA is depicted in figure $1 \mathrm{D}$.

At early follow-up, 9 of 14 patients with antibodies against surface antigens had improved by $\geq 1 \mathrm{mRS}$ point: 2 of 3 with LGI1 antibodies, 3 of 4 with CASPR 2 antibodies, and 4 of 7 with NMDAR antibodies. Whereas at baseline all patients with antibodies to surface antigens were dependent $(\mathrm{mRS}>2)$, 6 of 14 patients were independent ( $\mathrm{mRS} \leq 2,43 \%$ ) at early follow-up (figure 2). Rapid improvement is particularly evident by looking at seizure frequencies in patients with LGI1 and CASPR2 antibodies:

Figure 1 Standard treatment scheme and antibody titer changes
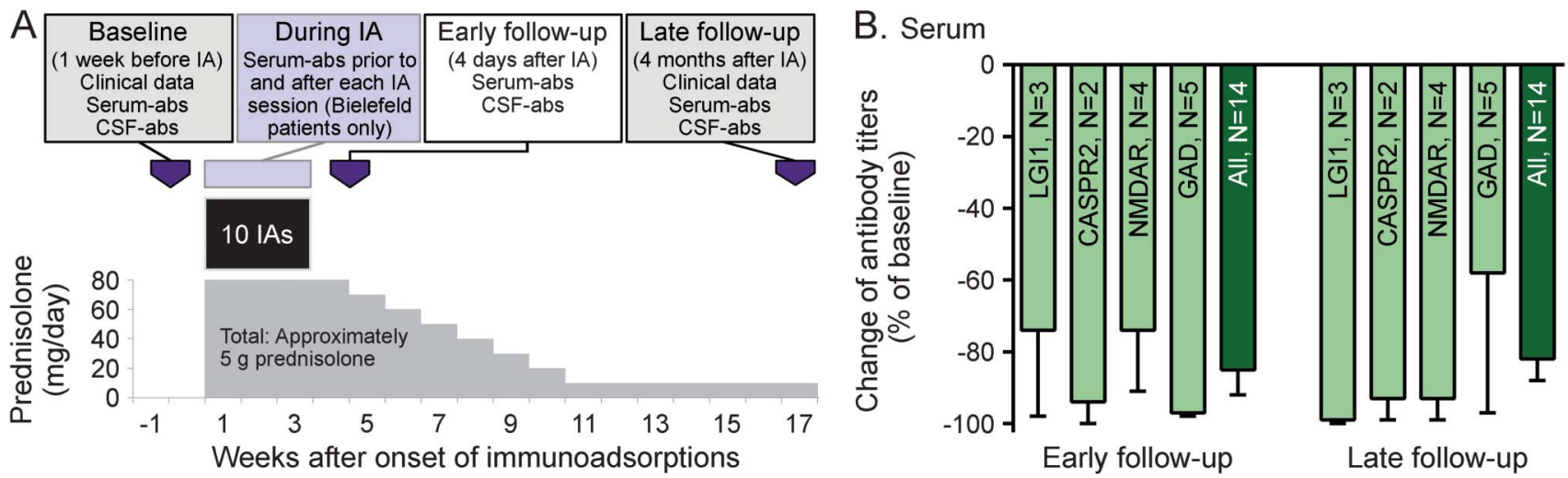

C. CSF
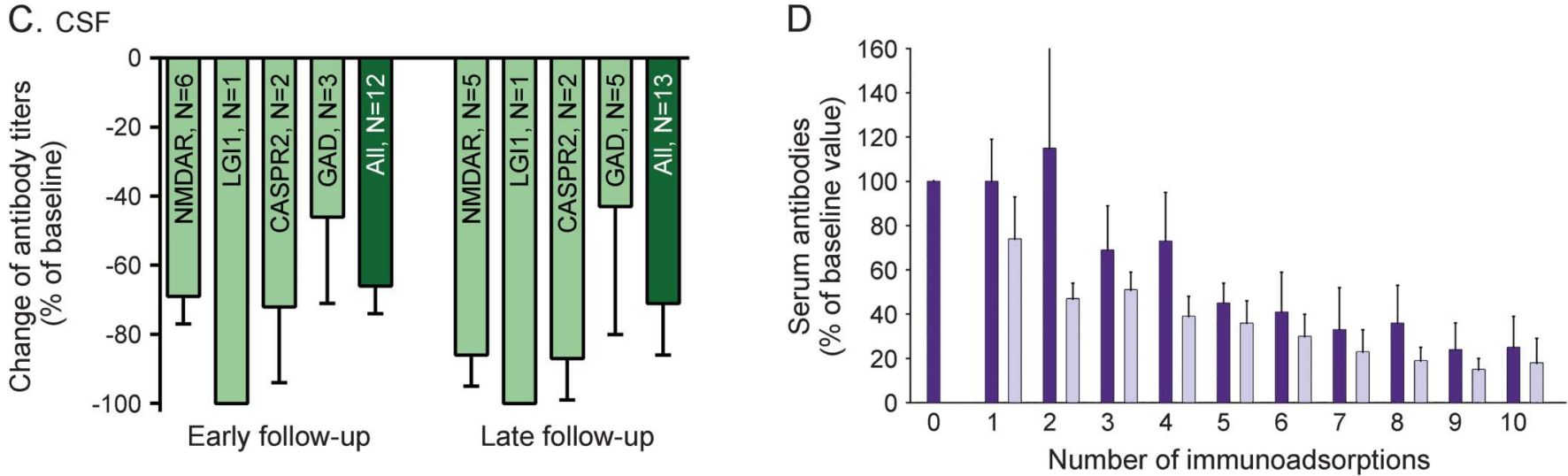

(A) Schematic depiction of the standard treatment schedule. (B-D) Changes of antibody titers in serum (B) and CSF (C) at early and late follow-up in relation to the antibody targets (means with standard errors of the means). (D) Antibody titers of all patients (pooled) from Bielefeld-Bethel ( $n=15$, means and standard errors of the means) on the immunoadsorption days directly prior to (dark purple bars) and after the immunoadsorptions (light purple bars). This shows the known sawtooth configuration that reflects the antibody redistribution between the vascular and extravascular compartments. Even after the fifth session, there is ongoing reduction of antibodies. CASPR2 = contactin-associated protein-2; GAD = glutamic acid decarboxylase; IA = immunoadsorption; LGI1 = leucine-rich glioma inactivated protein $1 ;$ NMDAR $=$ NMDA receptor. 


\begin{tabular}{|c|c|c|c|c|c|c|c|c|c|c|c|c|c|}
\hline \multicolumn{14}{|c|}{ Table 2 Individual patients' characteristics at early and late follow-up } \\
\hline \multicolumn{7}{|l|}{ Early follow-up } & \multicolumn{6}{|l|}{ Late follow-up } & \multirow[b]{2}{*}{$\begin{array}{l}\text { Pred total } \\
\text { doses, } \mathrm{mg}\end{array}$} \\
\hline $\begin{array}{l}\text { Antibody and } \\
\text { patient no. }\end{array}$ & $\begin{array}{l}\text { Time after } \\
\text { last IA, d }\end{array}$ & mRS & Seizures/wk & $\begin{array}{l}\text { Memory } \\
\text { (z scores) }\end{array}$ & $\begin{array}{l}\text { Serum antibodies } \\
\text { (titers 1:n) }\end{array}$ & $\begin{array}{l}\text { CSF antibodies } \\
\text { (titers 1:n) }\end{array}$ & $\begin{array}{l}\text { Time after } \\
\text { onset of IA, mo }\end{array}$ & $\mathrm{mRS}$ & Seizures/wk & $\begin{array}{l}\text { Memory } \\
\text { (z scores) }\end{array}$ & $\begin{array}{l}\text { Serum antibodies } \\
\text { (CBA titers 1:n) }\end{array}$ & $\begin{array}{l}\text { CSF antibodies } \\
\text { (CBA titers 1:n) }\end{array}$ & \\
\hline LGI1-A & 6 & 0 & 0 & -1.2 & 24 & 0 & 3.9 & 0 & 0 & -0.8 & 0 & 0 & 10,745 \\
\hline LGI1-B & 9 & 1 & 0 & -1.7 & 0 & 0 & 4.1 & 1 & 0 & -1.8 & 0 & 0 & 4,865 \\
\hline LGI1-C & 4 & 2 & 35 & -0.3 & 64 & 0 & 3.2 & 2 & 15 & -0.5 & 50 & 0 & 5,760 \\
\hline CASPR2-A & 3 & 2 & 0 & -2.2 & 2,000 & 64 & 4.5 & 1 & 0 & -0.9 & 5,000 & 32 & 3,540 \\
\hline CASPR2-B & 25 & 2 & 0 & -1.8 & ND & ND & 5.0 & 2 & 0.25 & -2.0 & ND & 2,000 & 6,000 \\
\hline CASPR2-C & 43 & 2 & 1 & ND & ND & 128 & 4.3 & 2 & 0 & -2.2 & 750,000 & ND & 6,000 \\
\hline CASPR2-D & 7 & 3 & 0 & -1.8 & 250 & ND & 3.0 & 2 & 0.75 & -2.0 & 250 & 8 & 4,140 \\
\hline NMDAR-A & 4 & 1 & 0 & -0.4 & 128 & 16 & 4.6 & 0.5 & 0 & 0.6 & 750 & 8 & 4,420 \\
\hline NMDAR-B & 1 & 1 & 0 & -1 & 0 & 1 & 2.4 & 0 & 0 & 0.4 & 0 & 0 & 2,620 \\
\hline NMDAR-C & 38 & 2 & 0 & -1.6 & 1,500 & 50 & 3.3 & 1.5 & 0 & -1.4 & 64 & ND & 4,790 \\
\hline NMDAR-D & 12 & 4 & 0 & -1.1 & ND & ND & 3.9 & 1 & 0 & 0.0 & ND & 4 & 0 \\
\hline NMDAR-E & 6 & 4 & 0 & -1.7 & 16 & 32 & 7.6 & 2.5 & 0 & -1.7 & 0 & 32 & 5,720 \\
\hline NMDAR-F & 8 & 5 & 0 & -3 & ND & 500 & 8.7 & 4 & 0 & ND & ND & ND & 6,960 \\
\hline NMDAR-G & 3 & 3 & 0 & -1.6 & 0 & 1 & 3.3 & 3 & 0 & -1.3 & 0 & 4 & 7,885 \\
\hline GAD-A & 0 & 2 & 0 & ND & 1,000 & ND & 3.4 & 2 & 1.75 & 0.5 & 8,000 & 2 & 1,440 \\
\hline GAD-B & 0 & 2 & 5 & ND & 500 & ND & 2.9 & 2 & 5.75 & -0.1 & 1,000 & 8 & 5,650 \\
\hline GAD-C & 0 & 2 & 1 & ND & 250 & 250 & 6.8 & 2 & 0.5 & ND & 16,000 & 500 & 1,675 \\
\hline GAD-D & 5 & 4 & 1 & -1.6 & 250 & 2 & 3.7 & 4 & 4 & -1.5 & 500 & 3 & 3,320 \\
\hline GAD-E & 1 & 2 & 15 & ND & 125 & 1 & 4.2 & 2.5 & 3.75 & -0.6 & 64 & 0 & 16,030 \\
\hline
\end{tabular}

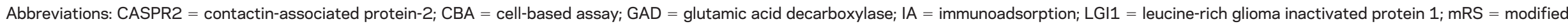
Rankin Scale; ND = not done; NMDAR = NMDA receptor; Pred = prednisolone. 

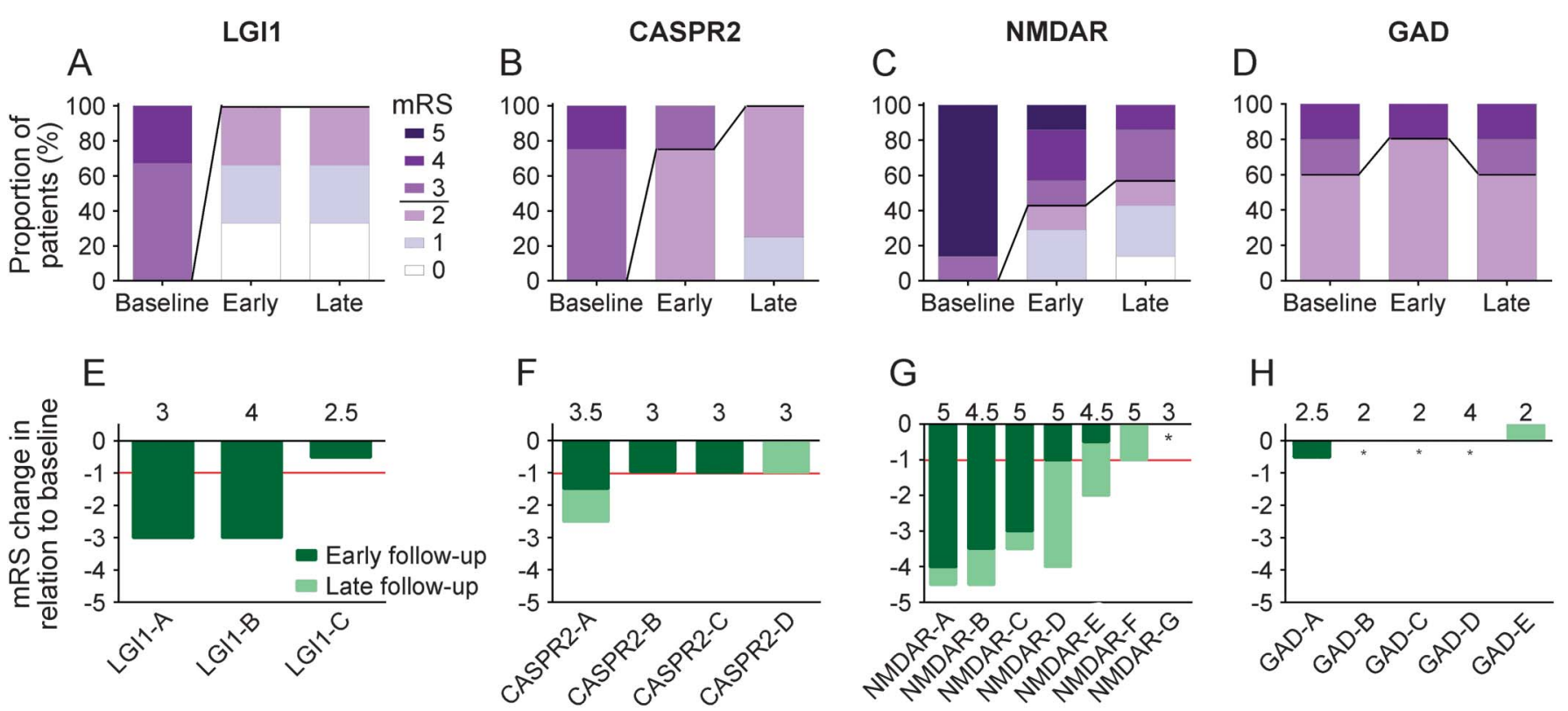

(A-D) Outcome is depicted as in the largest existing anti-NMDA receptor (NMDAR) encephalitis series 3. Modified Rankin Scale (mRS) values of the present series that lie in between whole numbers (because of the averaging procedure in case of divergent ratings) are rounded up to be as conservative as possible. The $\mathrm{mRS}$ values are given as shades of purple. The line in between $\mathrm{mRS} 2$ and 3 separates patients who can look after themselves (mRS $\leq 2$ ) from those who cannot live independently ( $m R S>2$ ). $(E-H)$ Individual $m R S$ changes are given (reduction indicates clinical improvement). Responder patients are those with mRS change of at least -1 (red lines). The dark green parts of the columns are changes from baseline to early follow-up; the light green parts are those that evolved in addition to that until late follow-up. Above each bar, baseline mRS values are indicated. Patient NMDAR-F improved between early and late followup while she underwent radio-chemotherapy of her small cell lung cancer. *No change in mRS. CASPR2 = contactin-associated protein-2; GAD = glutamic acid decarboxylase; LGI1 = leucine-rich glioma inactivated protein 1.

5 became immediately seizure-free. The LGI1 patients and CASPR2-B received no antiepileptic medication at all until early follow-up. CASPR2-C was on the same dose until late follow-up, and CASPR2-A had even been reduced (figure 3, $\mathrm{A}$ and $\mathrm{B})$. This is similar with memory performance of patients with NMDAR antibodies: 2 of 7 improved rapidly by more than 1 SD (figure 3C). Patients with antibodies to GAD did not improve in any area. Remarkably, 4 of 5 GAD-antibodypositive patients had disease durations of $>3$ years prior to IA.

At late follow-up, 12 of 14 patients (86\%) with surface antibodies were responders on the mRS compared to baseline. All but 1 patient with NMDAR and 2 with CASPR 2 antibodies had improved even beyond the performance at early follow-up, at least by $0.5 \mathrm{mRS}$ scores (figure 2, E-G). Patients with LGI1 antibodies did not improve further. Only 1 man with limbic encephalitis and LGI1 antibodies (LGI1-C) but already fixed hippocampal sclerosis and 1 woman with NMDAR antibodies (NMDAR-G) did not improve by $\geq 1 \mathrm{mRS}$ point (figure 2, E and G). However, despite a good early overall recovery, there was no recovery of memory performance in patients with LGI1 or CASRP2 antibodies within the observational period. No patient with GAD antibodies, 4 of 5 with long time lags until IA, improved at any point in time. The only patient with a small-cell lung cancer (NMDAR-F) showed no improvement at early follow-up but only after radio-chemotherapy between early and late follow-up.

Second IA series. A median of 4.5 (3.6-10.0) months after the last IA of the first series, 6 patients started a second IA series due to assumed incomplete effect of the first series: NMDAR-G, LGI1-C (with hippocampal sclerosis), CASPR2-D, CASPR2-B, GAD-A, and GAD-D. Five had a follow-up (median 4.6 months, range 2.9-6.0 months). None of these patients improved by $\geq 1 \mathrm{mRS}$ point compared to first late follow-up.

Adverse events. Adverse effects of IA were associated with the venous catheter: colonization of catheter tip with coagulase-negative staphylococcus requiring antibiotic therapy (LGI-2) and venous air embolism (GAD65-1). They resolved completely. Glucocorticoid therapy led to elevated blood glucose levels (CASPR2-D), acne (NMDAR-E), upper respiratory infection (LGI1-A), weight gain, and skin dryness and fungal infections (GAD65-3). Tachycardia and lip herpes were related to rituximab and cyclophosphamide in 


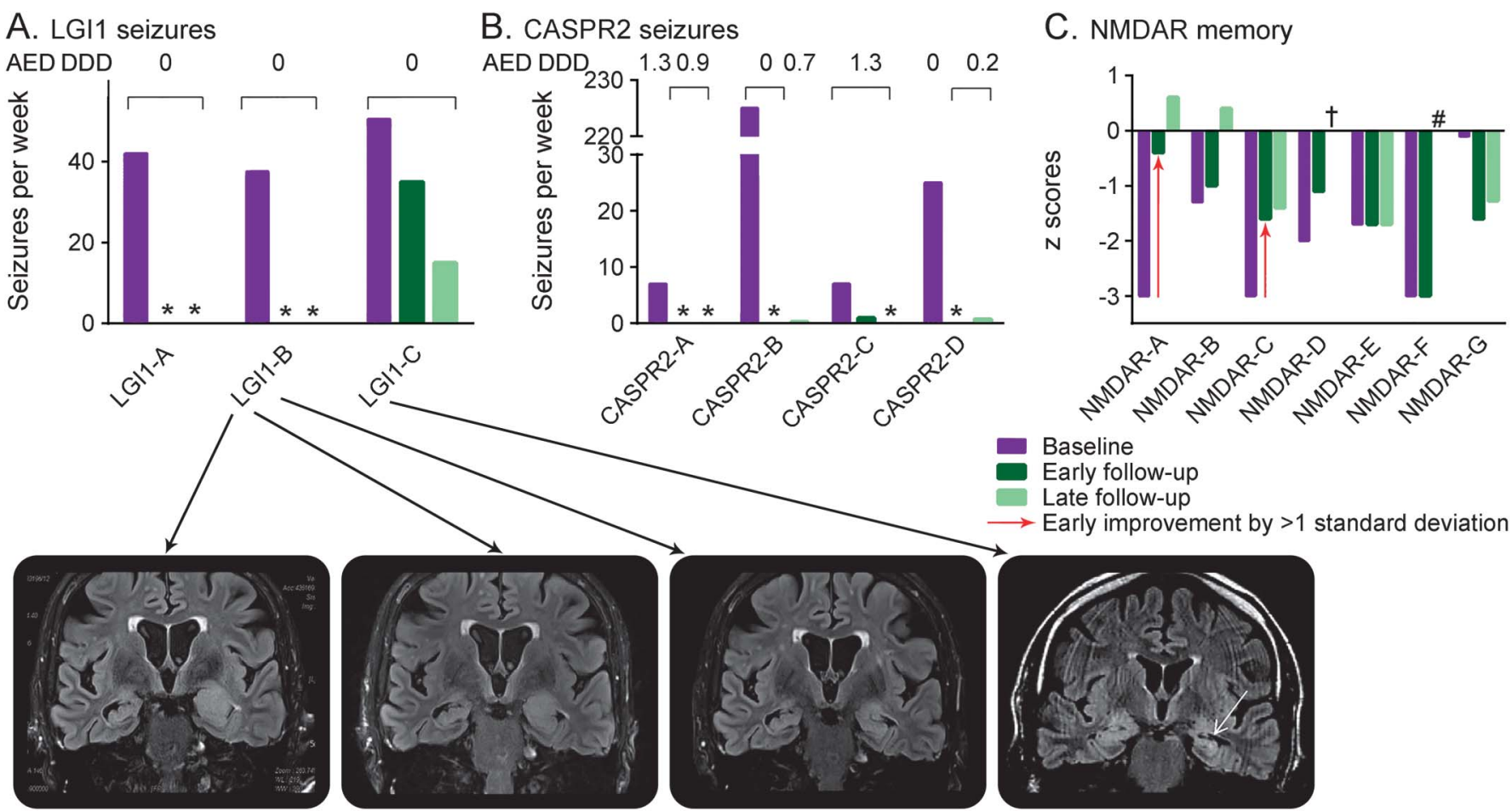

Seizures in patients with (A) leucine-rich glioma inactivated protein 1 (LGI1) antibodies and (B) contactin-associated protein-2 (CASPR2) antibodies. The antiepileptic drug defined daily dose (AED DDD) figures show that this was not due to anticonvulsive therapy. (C) Memory performance of anti-NMDA receptor (NMDAR) patients with 2 patients improving by $>1$ SD already at early follow-up (red arrows). Note the preservation of hippocampal volume in patient LGI1-B in contrast to the hippocampal sclerosis that was present from the beginning of IA in patient LGI1-C. This is a possible explanation for his incomplete response. *Seizure-free. "Value 0. \#No data. AED DDD according to WHO (http://www.whocc.no/atc_ddd_index/; accessed September 2, 2015).

1 patient (NMDAR-C) and depressive mood disturbance to mycophenolate mofetil (GAD65-1).

Four representative case descriptions. A 19-year-old woman (NMDAR-B) had encephalopathy with predominant psychiatric/cognitive impairment. Six days after symptom onset, she was treated at another hospital with $4 \times 1,000 \mathrm{mg}$ IV methylprednisolone without any effect. IA with concomitant prednisolone was started 6 weeks after symptom onset. One day after last IA, mRS was found to have gone down from 4.5 (baseline) to 1.0. Her memory returned almost into the normal range (from $z$ score -1.3 to -1.0 ). Three months later, she was back to school without memory impairment (mRS 0, memory $z$ score: +0.4 ) (figure 3C).

A 65-year-old woman (LGI1-B) started having multiple dyscognitive seizures per day. Levetiracetam was without effect and therefore discontinued at another institution. Diagnosis of limbic encephalitis with LGI1 antibodies and left hippocampal hyperintense lesion without atrophy was made 13 months after disease onset when she was not on antiepileptic drugs and had 5 seizures per day. She became seizurefree within 35 days after start of IA and $80 \mathrm{mg}$ oral prednisolone (figure 3A). Lamotrigine and lacosamide were intermittently administered, but quickly discontinued due to abdominal pain. An MRI 3 months after IA showed normalization of the hippocampus (figure 3A). Two years after disease onset, immunosuppressive and antiepileptic therapy had been terminated, with total remission of symptoms. One year later, she had a relapse with 3 seizures per day. After starting prednisolone $80 \mathrm{mg} / \mathrm{d}$ (but neither IA nor antiepileptic drugs), seizures stopped within 10 days.

A 60-year-old man (LGI1-C) developed LE due to LGI1 antibodies with frequent pilomotor seizures, hyperhidrosis, and memory and mood problems. At disease onset, IV methylprednisolone, oral prednisolone, and immunoglobulins had been administered with transient improvement of memory deficits and hyperhidrosis. Upon presentation to our center (41 months after symptom onset) and prior to IA-IS, he had MRI evidence of left-sided hippocampal sclerosis and right-sided amygdalar hyperintense signal (figure 3A). The patient refused antiepileptic pharmacotherapy. IA was followed by seizure reduction at early follow-up (figure 3A). Depressive symptoms persisted and required pharmacotherapy for 18 months. A second IA course was performed about 6 months later 
because depression and seizures continued and LGI1 antibodies increased. His mood improved but seizures became more frequent. We traced back this incomplete response to the fixed hippocampal sclerosis.

A 30-year-old man (GAD65-B) had pharmacoresistant temporal lobe seizures but normal memory performance and normal MRI. Four months after onset, he was started on IA and prednisolone. Levetiracetam was increased from $2 \mathrm{~g}$ to $3 \mathrm{~g}$ per day without effect on mRS or seizures. This was representative for all 5 GAD65 patients. Memory function remained normal.

DISCUSSION Two-thirds of patients with IgG antibodies to the surface antigens LGI1, CASPR2, and NMDAR responded within days to IA-IS therapy. The rapid achievement of seizure freedom in 5 of 7 LGI1/CASPR2-antibody-positive patients and the fast memory improvement in 2 of 7 patients with anti-NMDAR encephalitis are particularly impressive. In this retrospective, uncontrolled design, it is challenging to disentangle the effect of IA from (1) the natural course of autoimmune encephalitis, (2) the effect of previous immunologic interventions, and (3) the concomitant prednisolone therapy. Option 1 probably did not contribute to the rapid improvements during IA as documented at early follow-up. Options 2 and 3 may in part contribute to clinical improvement. The relapse in patient LGI1-B (see case description) was successfully treated with steroids alone, but this was a different disease episode. On the other hand, 2 patients had been treated with corticosteroids alone for 1 month (NMDAR-B) or with a combination of corticosteroids and cyclophosphamide for 6 months (CASPR2-A). Only after IA-IS therapy did the patients improve. Improvement was evident on mRS assessment within 3 days after last IA. This means that in these 2 patients a specific effect of IA can be uncoupled from a steroid effect in the same disease episode.

Other reports have also described patients with surface antibodies benefiting from plasmapheresis in combination with immunosuppression. ${ }^{31-34}$ This is compatible with a direct pathogenic effect of surface antibodies as demonstrated before. ${ }^{14,15}$ Incomplete improvement in patients LGI1-C and CASPR2-D is best explained by either preexisting or developing hippocampal atrophy that may result from complement activation with subsequent irreversible neuronal death. ${ }^{12,35}$

Our data do not argue in favor of IA in patients with temporal lobe epilepsy and GAD antibodies. Longer disease durations may have contributed to the inferior effect. Poor responses of patients with GAD antibodies have also been reported in other cohorts including recent onset patients. ${ }^{26}$ This suggests that $\mathrm{GAD}$ antibodies per se predict limited therapeutic effects of IA-IS. Other authors, however, describe a more positive influence of apheresis therapy in patients with antibodies against intracellular antigens. However, improvement was not stringently defined, ${ }^{36}$ short-lived, or absent. ${ }^{23}$ Poor response to antibody removal in these patients accounts for a primarily T-cell-based cytotoxicity ${ }^{8,12}$ and supports the idea of lack of antibody pathogenicity. ${ }^{37}$

In line with previous studies, ${ }^{20,38}$ our study data show that IA brought down antibody concentration in the periphery. Interestingly, CSF titers were also strongly reduced (by 66\% at early follow-up). In a previous plasma exchange study, however, only a mean drop of $23 \%$ of CSF antibody titers was observed. ${ }^{38}$ This is probably due to weaker reduction of peripheral IgG levels (mean 75\%) with reduced IgG redistribution from CSF across the blood-brain barrier along the serum-CSF-concentration gradient. ${ }^{38}$ This shift from CSF to the bloodstream may contribute to the sawtooth-like kinetics of antibody concentrations in serum (figure 1D). ${ }^{39}$ Long-term reduction of antibodies is probably due to the ongoing suppression of antibody secretion by corticosteroids.

Apart from the in part rapid effect of IA, evaluation of clinical usefulness of IA needs to take into account tolerability and costs. Addition of IA to corticosteroids at first glance increases costs and risks. In 2 of 19 patients, there were side effects that would have been serious adverse events in prospective trials, all related to the venous catheter. However, accelerated clinical recovery of patients treated with IA with reduced neurologic impairment, reduced or absent seizures, and possibly shorter periods of time spent in the hospital may outweigh risks and costs introduced by IA treatment.

This is a retrospective study with all inherent limitations. Therapeutic interventions were not totally uniform. Long disease duration until IA-IS in some patients may have contributed to an unfavorable outcome. Late diagnosis or failures of first therapeutic interventions were the reasons for the long time lag until IA-IS therapy. We did not study control patients, including patients with steroid therapy alone. On the basis of our data, the effect of IA cannot be clearly separated from that of concomitantly given steroids, IVIg, or other immunosuppressive therapies in some patients. The only patient with a tumor (NMDAR-F) did not improve during IA-IS therapy. Gradual recovery was reported after radio-chemotherapy.

Rapid improvement of patients with surface antibodies upon IA further supports the idea of a pathogenic effect of these antibodies. One might tentatively suggest that addition of IA to corticosteroids can speed up recovery by quick reduction of antibody titers. This 
might be an advantage in severely affected patients. In the absence of a control group and a masked outcome assessment, this study is considered grade IV evidence. Prospective controlled studies are needed to gain further data for the specific benefit of IA.

\section{AUTHOR CONTRIBUTIONS}

The study was conceptualized and initiated by M.D.O., K.S.G., N.M., and C.G.B. Antibody determination was done by C.G.B., C.B., D.M., and M. D.O. M.D.O., K.S.G., N.M., and C.G.B. searched the medical records and compiled the data. Patients were diagnosed and treated by C.G.B., N.M., K.S.G., C.B., M.D.O., H.W., H.L., M.B.-H., M.B., D.M., H.P., G.T., M.A.-T., and R.V. M.D.O., K.S.G., N.M., and C.G.B. wrote the manuscript draft, which was reviewed and refined by all authors for important intellectual content.

\section{ACKNOWLEDGMENT}

The authors thank Jutta Potthoff and Dagmar Bonhaus-Liebmann for technical assistance. This study was supported by the Society of Epilepsy Research Bethel, Bielefeld, Germany.

\section{STUDY FUNDING}

Diamed Medizintechnik GmbH, Cologne, Germany, and Fresenius Medical Care, Bad Homburg, Germany, supported this evaluation.

\section{DISCLOSURE}

M. Dogan Onugoren received travel funding and/or speaker honoraria from Fresenius Medical Care and Eisai. S.K. Golombeck performs immunoabsorption. C. Bien's employer receives payment for antibody tests. M. Abu-Tair is on the editorial board for Springermedizin elearning platform. M. Brand, M. Bulla-Hellwig, and H. Lohmann report no disclosures. D. Munstermann runs a commercial laboratory, which performed the detection of VGKC antibodies described in the study. External senders are charged for antibody diagnostics. H. Pavenstadt, G. Tholking, and R. Valentin report no disclosures. H. Wiendl serves on the scientific advisory boards for Bayer Healthcare, Biogen Idec, Sanofi-Genzyme, Merck Serono, Novartis, Roche, and Teva; received travel funding and/or speaker honoraria from Bayer Vital GmbH, Bayer Schering AG, Biogen, CSL Behring, EMD Serono, Fresenius Medical Care, Sanofi-Genzyme, Merck Serono, Omniamed, Novartis, and Teva; is on the editorial board for Journal of Clinical Practice, Journal of Neuroinflammation, and PLOS One; has consulted for Biogen Idec, Merck Serono, Novartis, Omniamed, Roche, and Sanofi-Genzyme; and received research support from Bayer Healthcare, Bayer Vital, Biogen Idec, Merck Serono, Novartis, Sanofi-Genzyme, Teva Pharma, German Ministry for Education and Research, Deutsche Forschungsgesellchaft, European Union, Else Kroner Fresenius Foundation, Fresenius Foundation, Hertie Foundation, NRW Ministry of Education and Research, Interdisciplinary Center for Clinical Studies Muenster, RE Children's Foundation, Sanofi-Aventis, and NovoNordisk. N. Melzer received travel funding and/or speaker honoraria from Biogen Idec, GlaxoSmithKline, Teva, and Fresenius Medical Care; performs immunoabsorption; and received research support from Fresenius Medical Care. C.G. Bien serves on the scientific advisory board for Eisai and UCB; received travel funding and/or speaker honoraria from Grifols, UCB, Eisai, GlaxoSmithKline, Destin Honoraria, Fresenius, Diamed, and Rasmussen encephalitis children project; received research support from Fresenius Medical Care, Diamed, University of Bonn, Hagedorn Foundation Bielefeld, and The Krankenhaus Mara; and receives payment for antibody tests (antineural antibodies) performed in the antibody laboratory (as those described in this study). Go to Neurology.org/nn for full disclosure forms.

Received May 13, 2015. Accepted in final form December 15, 2015

\section{REFERENCES}

1. Vincent A, Bien CG, Irani SR, Waters P. Autoantibodies associated with diseases of the CNS: new developments and future challenges. Lancet Neurol 2011;10:759-772.
2. Lancaster E, Dalmau J. Neuronal autoantigens: pathogenesis, associated disorders and antibody testing. Nat Rev Neurol 2012;8:380-390.

3. Titulaer MJ, McCracken L, Gabilondo I, et al. Treatment and prognostic factors for long-term outcome in patients with anti-NMDA receptor encephalitis: an observational cohort study. Lancet Neurol 2013;12:157-165.

4. Lancaster E, Lai M, Peng X, et al. Antibodies to the GABA (B) receptor in limbic encephalitis with seizures: case series and characterisation of the antigen. Lancet Neurol 2010;9: 67-76.

5. Irani SR, Alexander S, Waters P, et al. Antibodies to Kv1 potassium channel-complex proteins leucine-rich, glioma inactivated 1 protein and contactin-associated protein- 2 in limbic encephalitis, Morvan's syndrome and acquired neuromyotonia. Brain 2010;133:2734-2748.

6. Lai M, Huijbers MG, Lancaster E, et al. Investigation of LGI1 as the antigen in limbic encephalitis previously attributed to potassium channels: a case series. Lancet Neurol 2010;9:776-785.

7. Lancaster E, Huijbers MG, Bar V, et al. Investigations of Caspr2, an autoantigen of encephalitis and neuromyotonia. Ann Neurol 2011;69:303-311.

8. Dalmau J, Rosenfeld MR. Paraneoplastic syndromes of the CNS. Lancet Neurol 2008;7:327-340.

9. Saiz A, Blanco Y, Sabater L, et al. Spectrum of neurological syndromes associated with glutamic acid decarboxylase antibodies: diagnostic clues for this association. Brain 2008;131:2553-2563.

10. Malter MP, Helmstaedter C, Urbach H, Vincent A, Bien CG. Antibodies to glutamic acid decarboxylase define a form of limbic encephalitis. Ann Neurol 2010; 67:470-478.

11. Blumenthal DT, Salzman KL, Digre KB, Jensen RL, Dunson WA, Dalmau J. Early pathologic findings and long-term improvement in anti-Ma2-associated encephalitis. Neurology 2006;67:146-149.

12. Bien CG, Vincent A, Barnett MH, et al. Immunopathology of autoantibody-associated encephalitides: clues for pathogenesis. Brain 2012;135:1622-1638.

13. Hughes EG, Peng X, Gleichman AJ, et al. Cellular and synaptic mechanisms of anti-NMDA receptor encephalitis. J Neurosci 2010;30:5866-5875.

14. Ohkawa T, Fukata Y, Yamasaki M, et al. Autoantibodies to epilepsy-related LGI1 in limbic encephalitis neutralize LGI1-ADAM22 interaction and reduce synaptic AMPA receptors. J Neurosci 2013;33:18161-18174.

15. Planaguma J, Leypoldt F, Mannara F, et al. Human $\mathrm{N}$-methyl D-aspartate receptor antibodies alter memory and behaviour in mice. Brain 2015;138:94-109.

16. Newsom-Davis J, Pinching AJ, Vincent A, Wilson SG. Function of circulating antibody to acetylcholine receptor in myasthenia gravis: investigation by plasma exchange. Neurology 1978;28:266-272.

17. Pinching AJ, Peters DK, Davis JN. Remission of myasthenia gravis following plasma-exchange. Lancet 1976;2: 1373-1376.

18. Bender AN, Ringel SP, Engel WK, Daniels MP, Vogel Z. Myasthenia gravis: a serum factor blocking acetylcholine receptors of the human neuromuscular junction. Lancet 1975;1:607-609.

19. Toyka KV, Drachman DB, Griffin DE, et al. Myasthenia gravis: study of humoral immune mechanisms by passive transfer to mice. N Engl J Med 1977;296:125-131. 
20. Grob D, Simpson D, Mitsumoto H, et al. Treatment of myasthenia gravis by immunoadsorption of plasma. Neurology 1995;45:338-344.

21. Ullrich H, Kuehnl P. New trends in specific immunoadsorption. Transfus Apher Sci 2004;30:223-231.

22. Trebst C, Reising A, Kielstein JT, Hafer C, Stangel M. Plasma exchange therapy in steroid-unresponsive relapses in patients with multiple sclerosis. Blood Purif 2009;28: 108-115.

23. Mata S, Muscas GC, Naldi I, et al. Non-paraneoplastic limbic encephalitis associated with anti-glutamic acid decarboxylase antibodies. J Neuroimmunol 2008;199: 155-159.

24. Dalmau J, Lancaster E, Martinez-Hernandez E, Rosenfeld MR, Balice-Gordon R. Clinical experience and laboratory investigations in patients with antiNMDAR encephalitis. Lancet Neurol 2011;10:63-74.

25. Falip M, Carreno M, Miro J, et al. Prevalence and immunological spectrum of temporal lobe epilepsy with glutamic acid decarboxylase antibodies. Eur J Neurol 2012;19: 827-833.

26. Malter MP, Frisch C, Zeitler $\mathrm{H}$, et al. Treatment of immune-mediated temporal lobe epilepsy with GAD antibodies. Seizure 2015;30:57-63.

27. Graus F, Vega F, Delattre JY, et al. Plasmapheresis and antineoplastic treatment in CNS paraneoplastic syndromes with antineuronal autoantibodies. Neurology 1992;42: 536-540.

28. Helmstaedter C, Lendt M, Lux S. VLMT: Verbaler Lern- und Merkfähigkeitstest; Testhandbuch Hogrefe; 2001.

29. Helmstaedter C, Pohl C, Elger CE. Eine modifizierte Version des Diagnostikums für Cerebralschäden (DCS) zur Diagnostik räumlich-visueller Gedächtnisdefizite bei patienten mit Temporallappenepilepsie. In: Scheffner D, ed. Epilepsie 90. Reinbek, Germany: Einhorn-Presse; 1991:272-279.
30. Shin MS, Park SY, Park SR, Seol SH, Kwon JS. Clinical and empirical applications of the Rey-Osterrieth complex figure test. Nat Protoc 2006;1:892-899.

31. Agrawal S, Vincent A, Jacobson L, Milford D, Gupta R, Wassmer E. Successful treatment of anti-N-methyl-daspartate receptor limbic encephalitis in a 22-month-old child with plasmapheresis and pharmacological immunomodulation. Arch Dis Child 2010;95:312.

32. Wong SH, Saunders MD, Larner AJ, Das K, Hart IK. An effective immunotherapy regimen for VGKC antibodypositive limbic encephalitis. J Neurol Neurosurg Psychiatry 2010;81:1167-1169.

33. Reid JM, Foley P, Willison HJ. Voltage-gated potassium channel-associated limbic encephalitis in the West of Scotland: case reports and literature review. Scott Med J 2009;54:27-31.

34. Schimmel M, Bien CG, Vincent A, Schenk W, Penzien J. Successful treatment of anti-N-methyl-D-aspartate receptor encephalitis presenting with catatonia. Arch Dis Child 2009;94:314-316.

35. Körtvelyessy P, Bauer J, Stoppel CM, et al. Complementassociated neuronal loss in a patient with CASPR2 antibodyassociated encephalitis. Neurol Neuroimmunol Neuroinflamm 2015;2:e75. doi: 10.1212/NXI.0000000000000075.

36. Batchelor TT, Platten M, Hochberg FH. Immunoadsorption therapy for paraneoplastic syndromes. J Neurooncol 1998;40:131-136.

37. Gresa-Arribas N, Arino H, Martinez-Hernandez E, et al. Antibodies to inhibitory synaptic proteins in neurological syndromes associated with glutamic acid decarboxylase autoimmunity. PLoS One 2015;10:e0121364.

38. Furneaux HF, Reich L, Posner JB. Autoantibody synthesis in the central nervous system of patients with paraneoplastic syndromes. Neurology 1990;40:1085-1091.

39. De Masi R, Accoto S, Orlando S, et al. Dramatic recovery of steroid-refractory relapsed multiple sclerosis following fingolimod discontinuation using selective immune adsorption. BMC Neurol 2015;15:125. 


\section{Neurology \\ Neuroimmunology \& Neuroinflammation}

Immunoadsorption therapy in autoimmune encephalitides

Müjgan Dogan Onugoren, Kristin S. Golombeck, Corinna Bien, et al.

Neurol Neuroimmunol Neuroinflamm 2016;3;

DOI 10.1212/NXI.0000000000000207

This information is current as of February 26, 2016

\section{Updated Information \& \\ Services}

References

Citations

Permissions \& Licensing

Reprints including high resolution figures, can be found at:

http://nn.neurology.org/content/3/2/e207.full.html

This article cites 37 articles, 5 of which you can access for free at: http://nn.neurology.org/content/3/2/e207.full.html\#\#ref-list-1

This article has been cited by 1 HighWire-hosted articles:

http://nn.neurology.org/content/3/2/e207.full.html\#\#otherarticles

Information about reproducing this article in parts (figures,tables) or in its entirety can be found online at:

http://nn.neurology.org/misc/about.xhtml\#permissions

Information about ordering reprints can be found online: http://nn.neurology.org/misc/addir.xhtml\#reprintsus

Neurol Neuroimmunol Neuroinflamm is an official journal of the American Academy of Neurology.

Published since April 2014, it is an open-access, online-only, continuous publication journal. Copyright $(\subseteq$ 2016 American Academy of Neurology. All rights reserved. Online ISSN: 2332-7812.

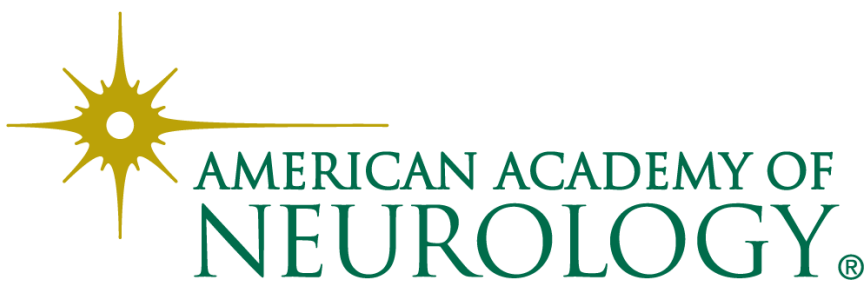

